\title{
The Effects of Water Content Variation on Adhesion Factor of Pile Foundation in Expansive Soil
}

\author{
Tjandra, D. ${ }^{*}$, Indarto ${ }^{2}$, and Soemitro, R.A.A. ${ }^{2}$
}

\begin{abstract}
Seasonal change causes variations in soil moisture content. On expansive soil, this condition influences soil moisture content in the active zone, which is approximately in five meters depth. The water content variation induces the changes in soil characteristics and these changes have an impact to adhesion factor of piles. The main objective of this research is to investigate the influence of water content variations on adhesion factor of piles. A series of laboratory experiments were conducted considering water content variations. A pile model made of concrete was penetrated to soil sample which was placed in a cylindrical tube of diameter about 15 times the diameter of the pile model. The pile model was loaded until failure to investigate the friction capacity. The results showed that the change of water content have great impact to adhesion factor of piles and its friction capacity decreased up to eight times from drying to wetting condition.
\end{abstract}

Keywords: Adhesion factor, friction capacity, water content.

\section{Introduction}

One of the most important things on expansive soil is variation of soil moisture content due to seasonal change. Variation of soil moisture content could be occurred approximately in the five meters depth which is generally termed as the active zone. Soil water evaporation during the dry season decreases soil moisture content. In wet season, when it rains, water infiltration into the soil increases the water content. This water content variation induces changes in physical and mechanical characteristics of the soil, especially for expansive soil [1-6]. The change of water content due to seasonal cycles would cause shrinking and swelling in expansive soil.

In the case of pile foundation, the change of water content due to drying and wetting cycles leads to changes in the friction capacity of piles. The water content variation induces the change in soil shear strength, which then leads to the change in adhesion factor. There are several empirical charts suggested by some researchers to determine the friction capacity of pile foundation with alpha method [7].

1, Ph.D. Candidate, Civil Engineering Department, Sepuluh Nopember Institute of Technology, Surabaya, INDONESIA and Civil Engineering Department, Petra Christian University, Surabaya, INDONESIA

${ }^{2}$ Civil Engineering Department, Sepuluh Nopember Institute of Technology, Surabaya, INDONESIA.

*Corresponding Author e-mail: danieltj@petra.ac.id

Note: Discussion is expected before November, $1^{\text {st }} 2013$, and will be published in the "Civil Engineering Dimension" volume 16, number 1, March 2014.

Received 10 April 2013.; revised 18 May 2013; accepted 15 June 2013
These charts show the relationship between adhesion factor and undrained shear strength. Unfortunately, it is not known whether these charts have considered water content variation in the field, especially in active zone. In this research, a series of laboratory experiments were conducted considering the water content variations. This research aimed to investigate the adhesion factor on friction capacity of piles under drying and wetting cycle.

\section{The Effect of Water Content Variation}

The change in water content greatly affects the strength of expansive soils, supporting structural foundations. Expansive soils are bound together by electrochemical bonds between individual particles, as soil cohesion. Water content significantly modifies the soil cohesion. As water content increases, soil cohesion decreases. The increase of water content can change the distance among particles, decreasing the strength of the inter-particle bonds. The decrease in bond strength results in a decrease in cohesion and a loss of shear strength.

In previous study, it was shown that soil cohesion in dry season reaches four times higher than in wet season. For example, in the dry season, cohesion was $149 \mathrm{kN} / \mathrm{m}^{2}$, while in wet season, cohesion decreased up to $37 \mathrm{kN} / \mathrm{m}^{2}$ [1].

In clayey soil, load capacity of pile was strongly determined by the friction between pile and soil. The friction capacity $\left(\mathrm{Q}_{f}\right)$ was determined using the equation as shown in Equation 1 [8]. 
$\mathrm{Q}_{\mathrm{f}}=\alpha \mathrm{cu}_{\mathrm{u}} \mathrm{A}_{\mathrm{s}}$

where $\alpha$ is adhesion factor, $c_{u}$ is undrained shear strength, and $\mathrm{A}_{\mathrm{s}}$ is the contact area between pile and soil.

There are several charts showing the relationship between undrained shear strength and adhesion factor suggested by some researchers, some of them are shown in Figure 1 [7].

Figure 1 shows that there is a wide scatter in the computed adhesion factors. Foundation engineers sometimes find difficulties in determining the proper value of adhesion factor. The problems seem that these charts do not cover the consideration of water content variation in the field.

\section{Research Method and Experimental Pro- cedure}

\section{Characteristics of Soil Sample}

In this research, field and laboratory experimental was conducted using soil sample taken from
Citraland, West Surabaya, Indonesia. The initial characteristics of soil sample, such as: water content, specific gravity, liquid limit, plastic limit, soil particle, and soil classification by Unified Soil Classification System (USCS) [9] are shown in Table 1.

The experimental research was conducted to investigate the friction capacity of piles under drying and wetting cycles. The friction capacities of piles were determined by the field and laboratory tests. In the field, test pile model with a diameter of $5.7 \mathrm{~cm}$ and a length of $1 \mathrm{~m}$ was inserted to the soil. The schematic of the field test is presented in Figure 2. The first step, the model pile was inserted to the soil to investigate the total capacity of piles (Figure 2a). Afterward, the pile was covered with casing and inserted to the soil to investigate the end bearing load only (Figure 2b). Thus, the friction load of piles could be determined by subtracting its end bearing load from its total capacity. This field experiment was done to validate the laboratory experiment.

Undisturbed soil sample was taken using a tube with a diameter of $15.24 \mathrm{~cm}\left(6^{\prime \prime}\right)$ and a length of 15

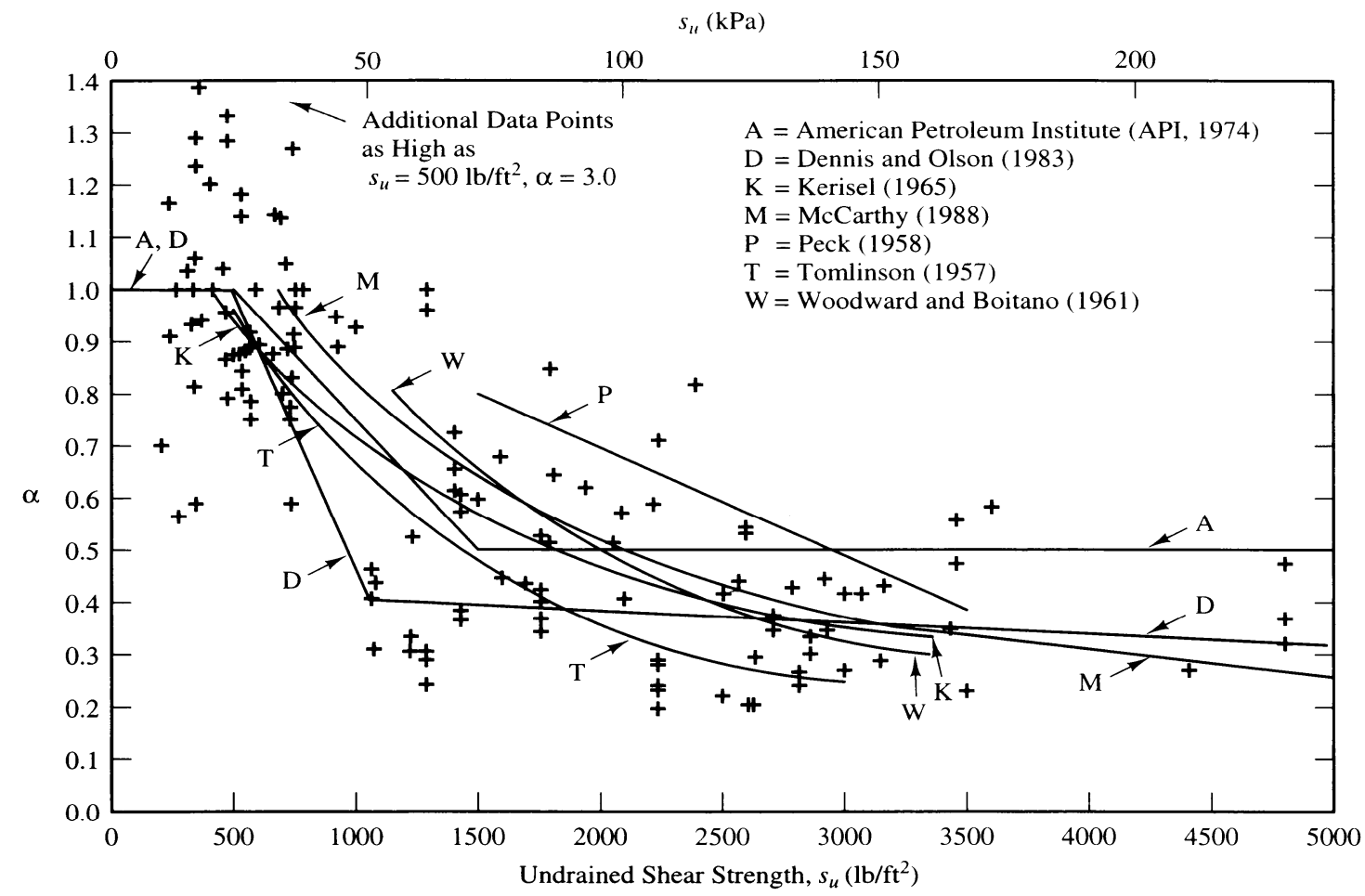

Figure 1. Adhesion Factor [7]

Table 1. Initial Characteristics of Soil Sample

\begin{tabular}{|c|c|c|c|c|c|c|c|c|}
\hline \multirow{2}{*}{$\begin{array}{l}\text { Water } \\
\text { content } \\
(\%)\end{array}$} & \multirow{2}{*}{$\begin{array}{l}\text { Specific } \\
\text { gravity }\end{array}$} & \multirow{2}{*}{$\begin{array}{c}\text { Liquid } \\
\text { limit } \\
(\%) \\
\end{array}$} & \multirow{2}{*}{$\begin{array}{c}\text { Plastic } \\
\text { limit } \\
(\%) \\
\end{array}$} & \multicolumn{3}{|c|}{ Soil particles } & \multirow{2}{*}{$\begin{array}{c}\text { Undrained shear } \\
\text { strength, cu } \\
(\mathrm{kPa}) \\
\end{array}$} & \multirow[b]{2}{*}{$\begin{array}{c}\text { Soil classification } \\
\text { (USCS) [9] }\end{array}$} \\
\hline & & & & $\begin{array}{c}\text { gravel } \\
(\%)\end{array}$ & $\begin{array}{l}\text { sand } \\
(\%)\end{array}$ & $\begin{array}{c}\text { fines } \\
(\%)\end{array}$ & & \\
\hline 44.5 & 2.65 & 109 & 30 & 0 & 0.11 & 99.9 & 26 & $\mathrm{CH}$ \\
\hline
\end{tabular}


$\mathrm{cm}$ as shown in Figure 3. Soil sample was taken at a depth of $1 \mathrm{~m}$. The weight of undisturbed soil sample was measured to ensure the uniformity of soil sample in all tubes. Afterward, undisturbed soil sample was wrapped in plastic to maintain its water content same as in its field condition.

In the laboratory experiment, concrete model piles were made with a diameter of $1 \mathrm{~cm}$ and a length of $30 \mathrm{~cm}$. As shown in Figure 4, a test pile was inserted to the soil sample tube to investigate its friction capacity. The soil sample tube was made from PVC with $15.24 \mathrm{~cm} \mathrm{(6")} \mathrm{diameter,} \mathrm{considering} \mathrm{the}$ boundary effect of 15 times pile diameter [10-11].
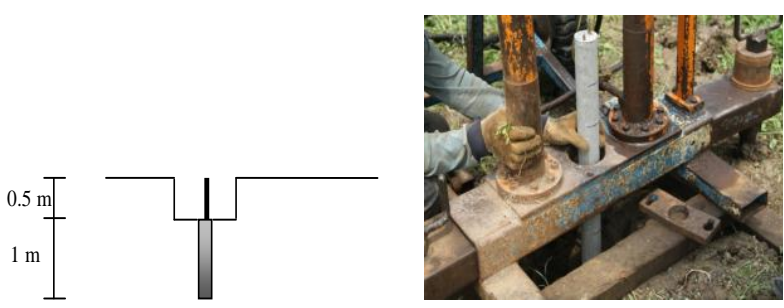

(a)

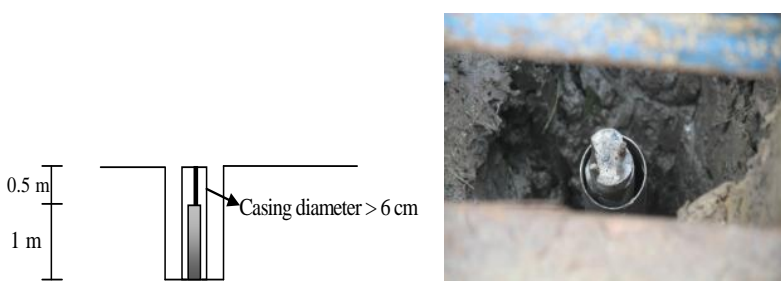

(b)

Figure 2. Field Experiment (a) Total Pile Load (b) End Bearing

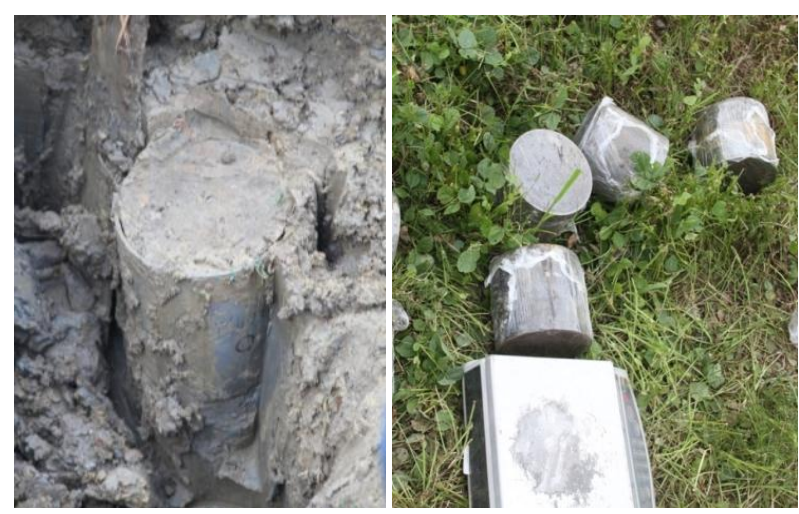

Figure 3. Soil Sampling
The soil sample in the tube was tested to measure the water content variation. Based on the secondary data obtained from a soil test company in Surabaya, the variation of soil moisture content in West Surabaya due to seasonal change throughout the year ranges from $25 \%$ to $55 \%$ (Figure 5). The water content variation in this research is showed in Table 2.

In this study, undrained shear strength tests were conducted with water content variation. The undrained shear strengths were obtained from the unconfined compression test for drying condition and vane test for wetting condition. Based on pile friction capacity and undrained shear strength values, adhesion factor could be calculated by dividing pile friction capacity with undrained shear strength and contact area between pile and soil as shown in Equation 1.

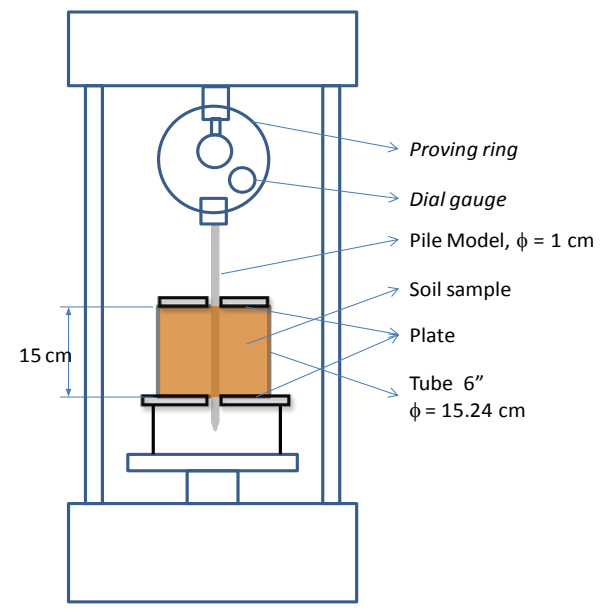

Figure 4. Laboratory Model Pile

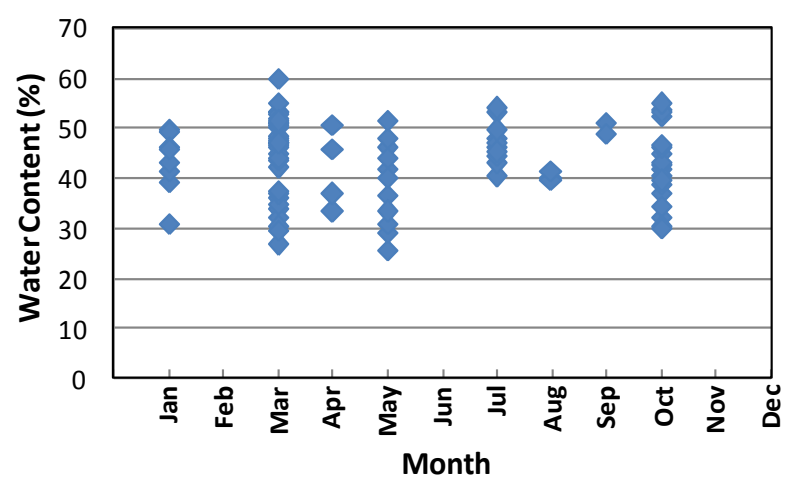

Figure 5. Variation of Water Content at West Surabaya in a Year

Table 2. Drying and Wetting Condition

\begin{tabular}{lccccccccc}
\hline & Wetting & Wetting & Wetting & \multirow{2}{*}{ Initial } & Drying & Drying & Drying & Drying & Drying \\
& $15 \%$ & $10 \%$ & $5 \%$ & & $20 \%$ & $30 \%$ & $40 \%$ & $50 \%$ \\
\hline Water Content, $\mathrm{w}_{\mathrm{c}}(\%)$ & 51.18 & 48.95 & 46.73 & 44.5 & 40.05 & 35.60 & 31.15 & 26.7 & 22.25 \\
\hline
\end{tabular}

Note: Drying $\mathrm{x} \% \rightarrow \mathrm{w}_{\mathrm{c}}(\mathrm{x})=\mathrm{w}_{\mathrm{c}}$ (initial) $-\mathrm{x} \% \mathrm{w}_{\mathrm{c}}$ (initial)

Wetting $\mathrm{y} \% \rightarrow \mathrm{w}_{\mathrm{c}}(\mathrm{y})=\mathrm{w}_{\mathrm{c}}$ (initial) $+\mathrm{y} \% \mathrm{w}_{\mathrm{c}}$ (initial) 


\section{Experimental Result}

The influences of water content variations on adhesion factor of piles were investigated through a series of field and laboratory testing. Laboratory loading test was conducted to represent the loading test at the field. Friction capacity of concrete piles at the laboratory and field were $0.154 \mathrm{~kg} / \mathrm{cm}^{2}$ and 0.192 $\mathrm{kg} / \mathrm{cm}^{2}$, respectively. It can be concluded that the accuracy of concrete model pile is $80 \%$.

\section{Drying - Wetting}

Drying and wetting due to seasonal change occurred in the active zone, which has a depth about five meters. The water content variation induces the change in friction capacity of pile. The relationship between friction load and displacement of model piles is shown in Figure 6. In general, frictions load decreased with the increasing water content. Drying and wetting cycles greatly affected the friction

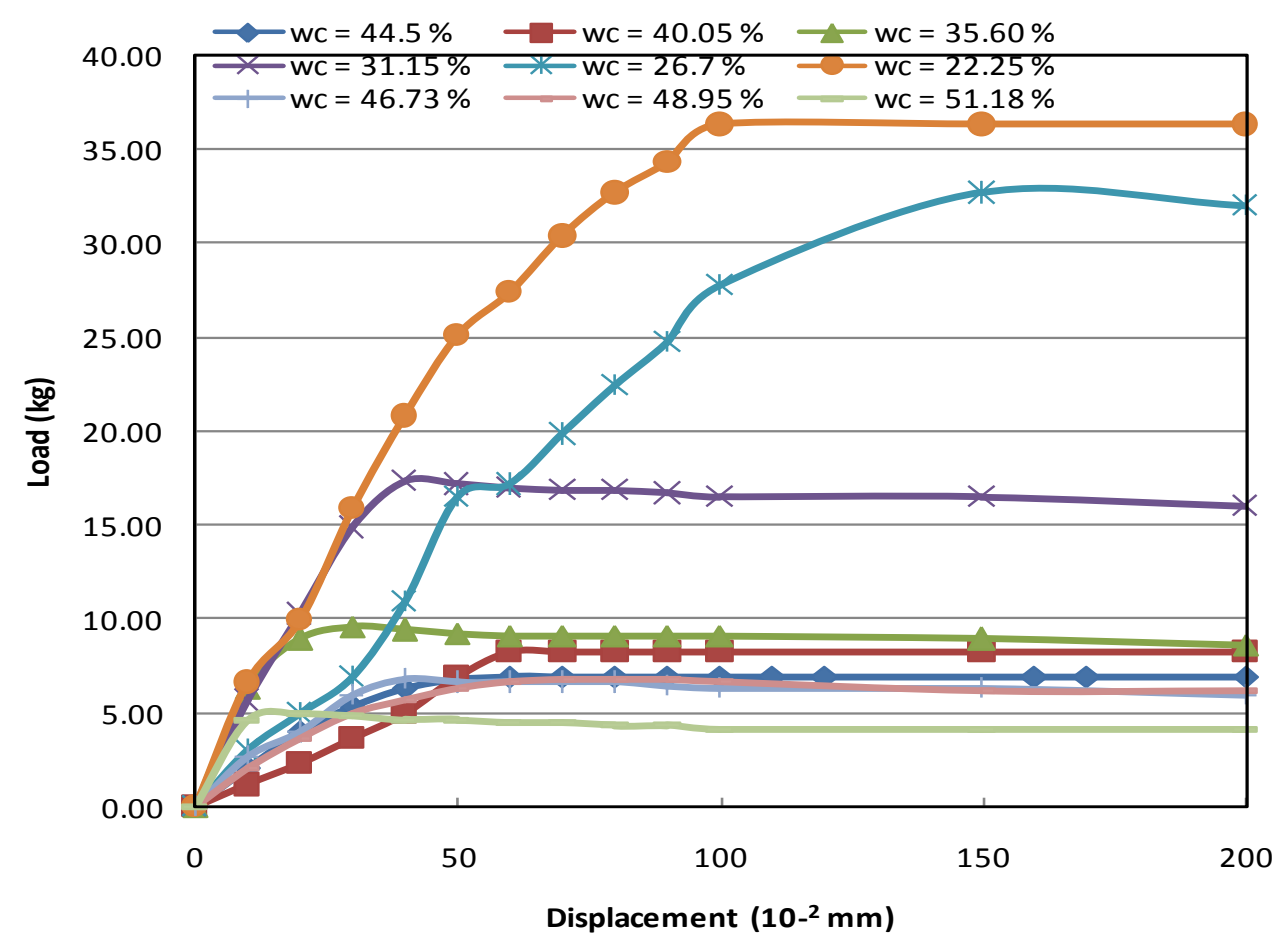

Figure 6. Load - Displacement Curve

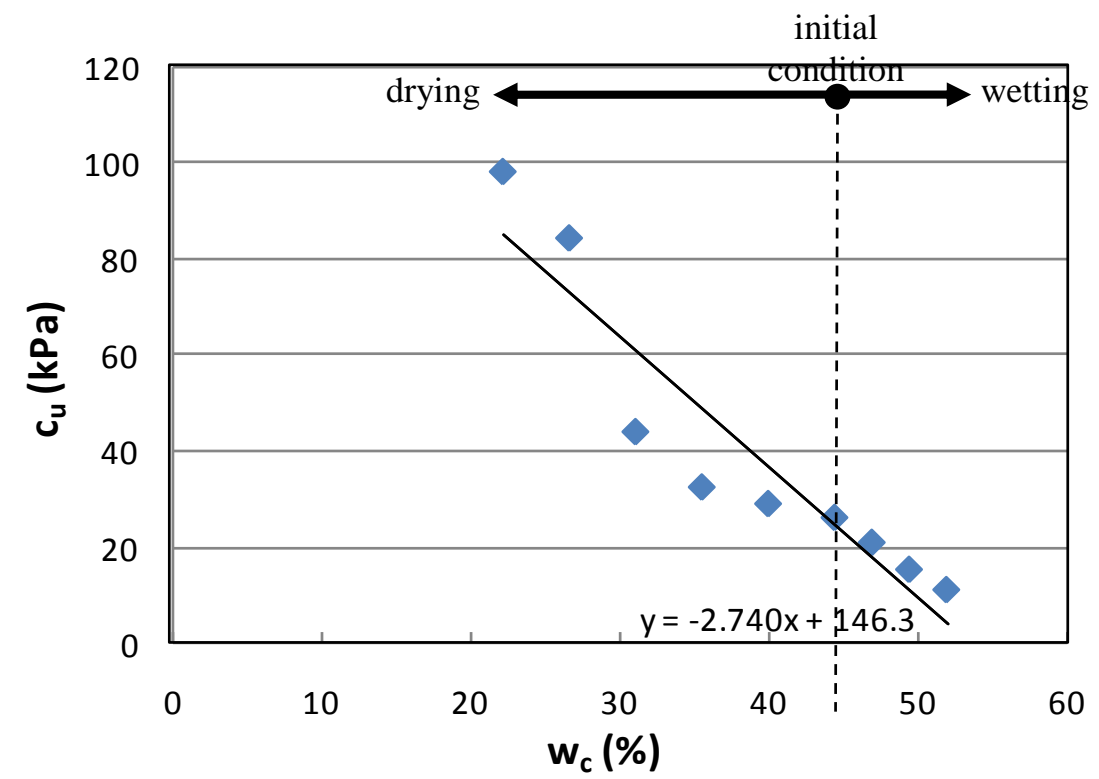

Figure 7. Undrained Shear Strength under Drying-Wetting Condition 
capacity of piles. The difference of friction capacity in the range of water content between $51.18 \%$ (wetting $15 \%$ ) to $22.25 \%$ (drying $50 \%$ ) was 8.7 times. Because of this phenomenon, in the real pile design, the friction capacity in the active zone is usually neglected.

\section{Undrained Shear Strength}

The change in water content greatly affects the soil strength of expansive soils. In Figure 7, in wetting condition, undrained shear strength decreased. The decrease of undrained shear strength is caused by the pore water pressure increased and effective stress of soil decreased. Otherwise, in drying con- dition, undrained shear strength increased. The difference of undrained shear strength in the range of water content between $51.18 \%$ (wetting $15 \%$ ) to $22.25 \%$ (drying 50\%) was 8.2 times.

\section{Adhesion Factor}

The relationship between undrained shear strength with adhesion factor is shown in Figure 8. The relationship between undrained shear strength, $\mathrm{cu}$, and adhesion factor, $a$, which is suggested by some researcher as shown in Figure 1, have approximately the same trend line with the chart shown in Figure 8. However, when $\mathrm{cu}$ value is higher than $30 \mathrm{kPa}$, adhesion factor increases again with increasing

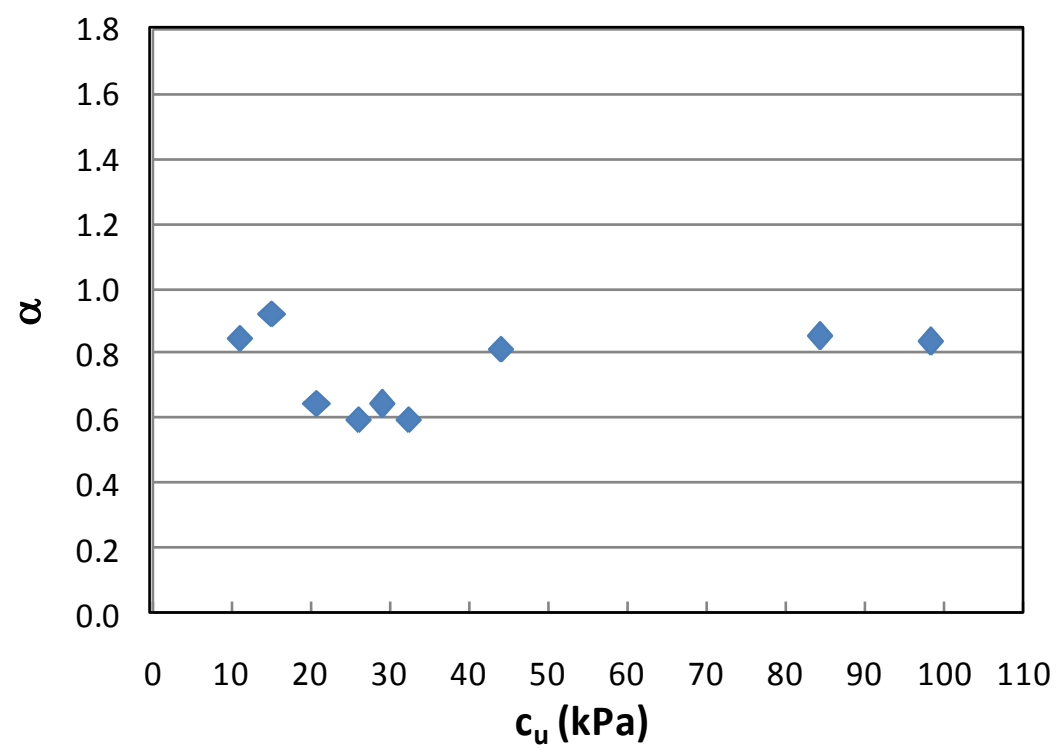

Figure 8. Initial Adhesion Factor

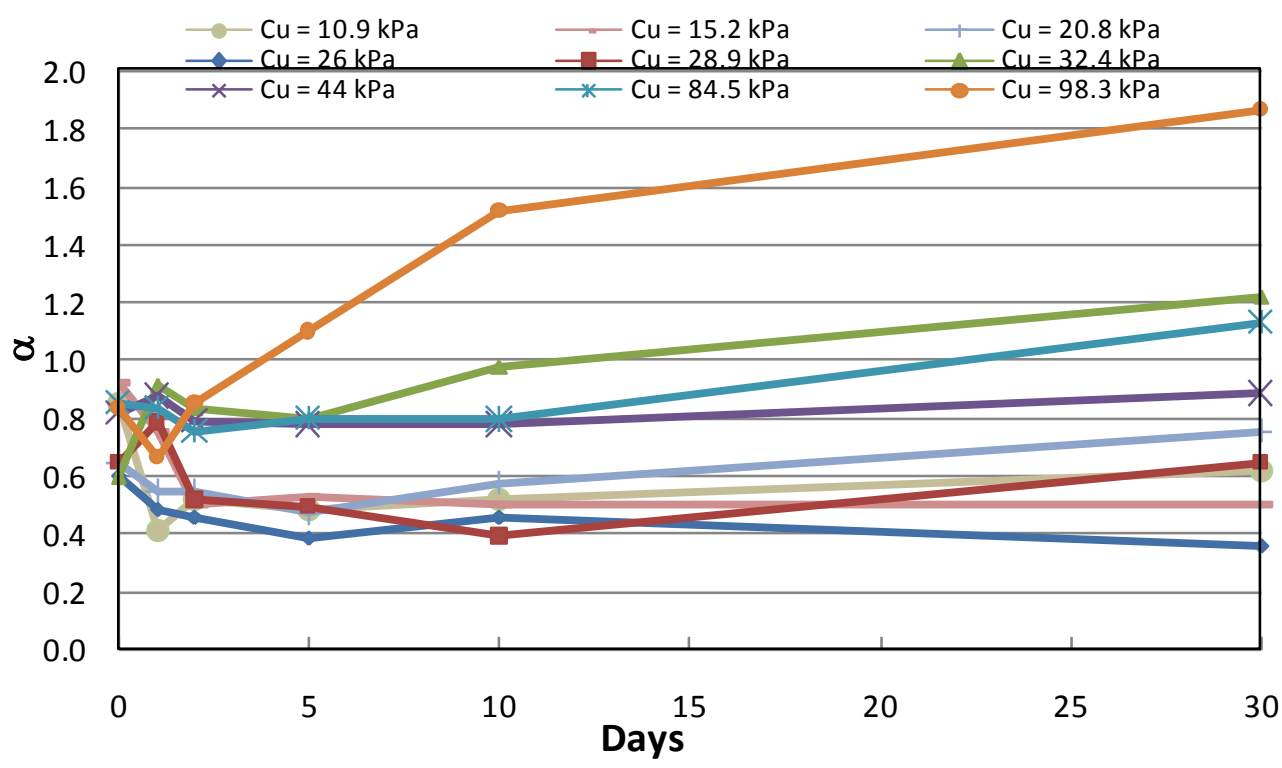

Figure 9. Adhesion Factor with Time Variation 
undrained shear strength. After $\mathrm{c}_{\mathrm{u}}$ value reached 45 $\mathrm{kPa}$, adhesion factor has constant value of 0.8 . Normally for all clayey soil, if undrained shear strength increases, the adhesion should decrease. But in this case, the increase of undrained shear strength is due to the decrease of moisture content. There might be some connection with the increase of suction at dryer condition. When the soil shrinks, it may also suck any material within, hence the increasing of adhesion factor.

Pile friction capacity and adhesion factor are also varied with time. By the variation of time at the same water content condition, pile friction capacity and adhesion factor also varied. The changes of adhesion factor with time variation is shown in Figure 9. In weaker soil with $c_{u}$ value smaller than $30 \mathrm{kPa}$, mostly, adhesion factor at 30 days is still lower than that at initial day although it seems to increase after 10 days. However, in stronger soil with $\mathrm{c}_{\mathrm{u}}$ value higher than $30 \mathrm{kPa}$, adhesion factor at 30 days is higher than that at initial day. In line with previous explanation about suction phenomena, when $c_{u}$ value reaches $30 \mathrm{kPa}$, suction appears between soil and pile. This suction may also increase with increase of time at dryer condition.

\section{Conclusions}

A series of experimental study was conducted to investigate the effect of water content variation on adhesion factor on pile friction capacity in the active zone, which approximately has a depth of five meters from soil surface. The following is a summary of the conclusion from this investigation:

1. Loading test at the laboratory can represent the loading test at the field with $80 \%$ accuracy.

2. Drying and wetting greatly affect the friction capacity of pile foundation in the active zone. Friction capacity decreased with the increasing water content. The range of friction capacity variation between water content $51.18 \%$ to $22.25 \%$ is up to 8.7 times. This result supports the design practice to neglect the friction capacity in the active zone.

3. Drying and wetting greatly affect the soil strength. The undrained shear strength decreased with increasing water content. The range of undrained shear strength between water content $51.18 \%$ to $22.25 \%$ is up to 8.2 times.

4. This research shows approximately the same trend of the relationship between undrained shear strength and adhesion factor suggested by some researcher [7]. Contrary to the suggested graph, when $c_{u}$ value is higher than $30 \mathrm{kPa}$, adhesion factor increased with the increasing undrained shear strength. This phenomenon is thought that the higher undrained shear strength was obtained by lowering the water content, which increased the suction of the adhering soil.

For a particular soil, when the strength is lower than $30 \mathrm{kPa}$, adhesion factor decrease with time. If the strength is increased above $30 \mathrm{kPa}$ by lowering the water content, adhesion factor increase, with time. This phenomenon is also thought that suction may also increase with time at dryer condition.

\section{References}

1. Yalcin, A., A Geotechnical Study on the Landslides in the Trabzon Province, NE, Turkey, Applied Clay Science, 52, 2011, pp. 11-19,

2. Indarto, Drying and Wetting Cyclus against Foundation Failure, Proceedings of HATTI Seminar, Bandung, 2008.

3. Muntaha, M., Soemitro R.A., Noor Endah, and Indarto, Characteristics of Tropical Residual Soils in Arjasa Jember of East Java, International Journal Academic Research, 2(5), 2010.

4. Au, S.W.C., Rain-Induced Slope Stability in Hong Kong, Engineering Geology, 51, 1998. pp. 1-36.

5. Badawi, S. and Indarto, Behavior of Expansive Undisturbed Soil and Remolded Soil under Drying and Wetting Cycle, National Seminar VI 2010 Civil Engineering ITS Surabaya, 2010, pp. 105-112.

6. Shayea, N.A., The Combined Effect of Clay and Moisture Content on the Behavior of Remolded unsaturated Soils, Engineering Geology, 62, 2001, pp. 319-342.

7. Coduto, D.P., Foundation Design Principles and Practices, Prentice-Hall, Inc, New Jersey, 2001.

8. Tomlinson, M.J., Foundation Design and Construction, Prentice Hall, 2001.

9. Das, B.M., Principles of Geotechnical Engineering, California: PWS Publishing, 1999.

10. Mhaidib, A.I., Effect of Rate of Loading on Uplift Capacity of a Model Pile in Clay, Proceedings of the Eleventh (2001) International Offshore and Polar Engineering Conference, Stavanger, Norway, 2001, pp. 656-661,

11. Poulos, H.G., Effect of Pile Driving on Adjacent Piles in Clay, Canadian Geotechnical Journal, 31, 1994, pp. 856-867. 